\title{
Formulating the Electric Vehicle Battery Supply Chain in Indonesia
}

\author{
Albert Siahaan ${ }^{1}$, Muhammad Asrol ${ }^{1}$, Fergyanto E Gunawan ${ }^{1}$, Firdaus Alamsjah ${ }^{1}$ \\ ${ }^{1}$ Industrial Engineering Department, BINUS Graduate Program - Master of Industrial Engineering, \\ Bina Nusantara University, Jakarta, 11480, Indonesia
}

\begin{abstract}
The need for electric vehicle (EV) in the world is currently showing an increase, including Indonesia. Indonesia's Lithium reserves of around 4.5 billion tons and is the largest in the world, about $32.7 \%$. This study aims to formulate a strategy for the EV battery supply chain in Indonesia to support the industry. Data was collected through questionnaires from experts using AHP-CPI. Center of Gravity was applied to determine the specific location and the supply chain strategy was formulated with SWOT. The research resulted in the best alternative location for an EV battery factory in the IMIP-Morowali industrial area, Central Sulawesi with score 486.55. Two grand strategies were suggested for EV supply chain industry, conducting research and improving human resources through training and technology transfer from investors by providing incentives.
\end{abstract}

Keywords - battery, electric vehicle, Center of Gravity, location alternative, supply chain, strategy.

\section{Introduction}

The development of electric cars in the world shows a positive thing, world oil reserves reached a new oil

DOI: 10.18421/TEM104-54

https://doi.org/10.18421/TEM104-54

Corresponding author: Muhammad Asrol, Industrial Engineering Department, BINUS Graduate, Program - Master of Industrial Engineering, Bina, Nusantara University, Jakarta, 11480, Indonesia.

Email: muhammad.asrol@binus.edu

Received: 13 August 2021.

Revised: 03 November 2021.

Accepted: 10 November 2021.

Published: 26 November 2021.

(c) BY-NC-ND (C) 2021 Albert Siahaan et al; published by UIKTEN. This work is licensed under the Creative Commons Attribution-NonCommercial-NoDerivs 4.0 License.

The article is published with Open Access at www.temjournal.com production record of 92.6 million barrels per day in 2017 , estimates of total oil reserves and world oil reserves range from 1.64 - 1.66 trillion barrels. According to the Energy Information Administration (EIA), the total world oil consumption in 2018 was 99.55 million barrels per day, an estimate that the world's total oil reserves are 1.66 trillion barrels, so they will only last for 40-45 years [1].

Air pollution in many countries of the world in 2005 has worsened, measurements of PM10 (particles $50 \mathrm{mkg} / \mathrm{m} 3$ ) in Africa $=40-150 \mathrm{mkg} / \mathrm{m} 3$, Asia (35-220 mkg/m3), Australia/New zeland $=28$ $127 \mathrm{mkg} / \mathrm{m} 3)$, Canada/USA $=20-60 \mathrm{mkg} / \mathrm{m} 3$, Europe $=20-70 \mathrm{mkg} / \mathrm{m} 3$, and Latin America $=30$ $129 \mathrm{mkg} / \mathrm{m} 3$, [2].

The increase in air pollution in big cities in Indonesia such as higher carbon dioxide $\left(\mathrm{CO}_{2}\right)$ emissions cause the air to deteriorate from the smoke from land transportation modes and contributes about 80. This is also influenced by an increase in energy consumption of around 6-8\% per year, and has an impact on NOx increase of up to $51 \%$ (from 814 $\mathrm{kt} / \mathrm{yr}$ in 2015 to $1,225 \mathrm{kt} /$ year in 2030), PM2.5 up to $26 \%$ (from $87.7 \mathrm{kt} /$ year in 2015 to $110.5 \mathrm{kt} /$ year in 2030), as well as other pollutants such as $\mathrm{SO}_{2}, \mathrm{PM} 10$, VOC, and $\mathrm{O}_{3}$ [3].

The use of two-wheeled and four-wheeled electric vehicles as a mode of land transportation is an alternative to reduce the impact of the energy crisis and air pollution. The development of electric cars in Indonesia has increased, in 2010 as many as 390 units and increased in 2016 to 805,320 units. Batteries are the main component of electric cars, and account for about $40 \%$ of the price of electric cars. The largest cost component for the manufacture of electric car batteries is the material cost which reaches approximately $60 \%$ of the total cost of making batteries [4]. Most electric cars use lithium ion (LiB) batteries with lithium as the cathode material and graphite as the anode material. The cathode material gives the highest contribution to the price of lithium batteries, which is around 34\% [5].

Indonesia's lithium reserves are around 4.5 billion tons and Indonesia is the country with the largest nickel ore reserves in the world, around $32.7 \%$ of the 
world's nickel reserves are in Indonesia. So it is estimated that it can last up to 39 years for Indonesia, and Indonesia has the potential to become the World's Largest Lithium Battery Producer [6]. Electric car (EV), the battery is the most important component, is the only source of power, the electrical energy stored in the battery is the only source of energy to drive an electric car / EV and its accessories, so that the storage capacity of electric power is much larger, so it's bigger. In addition to requiring maintenance, $\mathrm{EV}$ car batteries also require usage management so that their service life can last a long time according to the manufacturer's warranty, because improper use of batteries can result in drastically reduced battery capacity [7].

The Indonesian government's policy regarding the Acceleration of the Battery Electric Vehicle Program (Battery Electric Vehicle) for Road Transportation (Perpres No. 55/2019) is also supported by the regulation of the general national energy plan in Presidential Regulation No. 22/2017 concerning the General National Energy Plan (RUEN).

The formulation of the electric battery supply chain in Indonesia has complex challenges, seeking the widest possible information about sources of nickel raw materials and nickel smelter factories and EV battery precursors on the islands of Maluku, Sulawesi, Papuan and Kalimantan. Including the sources of plans for electric car/EV manufacturers/factories on the island of Java (Cikarang, Subang, Batang) as well as potential electric car consumers in several cities spread throughout Indonesia. Therefore, the supply chain as a network in adding value to a product is a global network that is used to deliver products or services from raw materials to end users (consumers) in the form of flows of goods, information and financial flows [8].

This study aims to determine a specific location for the construction of a cell battery factory to support the electric car industry in Indonesia. Determining the right location through various appropriate criteria can create a strong supply chain. A strategy formulation is also suggested to maintain the supply chain to enhance the EV and battery industry in further implementations. This paper is organized as follows: in this part, the background and the research objective are revealed. At the part 2, literature review is organized to provide information and current research in the related topics. Part 3 describe the research method, research framework and stages, data analysis and technique, data acquisition and collection. Result and discussion is delivered at the part 3. Finally, conclusion is provided at part 4.

\section{Literature Review}

\section{EV battery technology}

EV batteries are different from SLI (Starting, Lighting and Ignition) batteries, EV types such as HEV (Hybrid-electric vehicle), BEV (Battery electric vehicle), and PHEV (Plug-in hybrid electric vehicle) use different types of batteries.

The types of batteries used are NiMH batteries, Lithium-Ion (Li-Ion)-Lib, ead Acid (SLA), Ultracapacitor, Zebra (Zero Emission Research Activity) batteries [7]. The most widely used type of $\mathrm{EV}$ is the Lithium-Ion (Li-Ion) battery -LiB, and is called a traction battery pack. The power to weight ratio is very high (the same weight gets a larger kwh so that the battery weight is reduced and the charging interval is longer long time), high energy efficiency, good high temperature performance, damaged batteries can be recycled, and are most widely used by BEV and PHEV types of electric cars.

\section{Supply Chain Management}

Supply Chain Management consists of planning and managing all activities involving procurement, change, and all logistics management activities, including coordination and cooperation with partners [9]. Supply chain is how to manage three flows within the company such as: commodity/product flow, information flow and cash flow/Cash Flow and supply chain element strategy.

The supply chain management have to manage stakeholders to improve the performance. Stakeholders responsible to maintain own performance and risk mitigation to minimize the overall supply chain impact in performance. Before that, in a proposed supply chain network, a potential location has to be managed. The alternative location has to determine to compare each other and find the best alternative. A facility location and alternative location selection is the part of supply chain management.

Decisions in formulating a supply chain network have a significant impact on performance because defining a supply chain is configuring and setting boundaries within which other supply chain drivers can be used to reduce supply chain costs or to increase profits. All network formulation decisions affect each other and have be taken into account. In examining the various factors that influence the decision to formulate a supply chain network, several factors are described for determining the location and supply chain network. 
This research considers strategic and competitive factors to find the potential location for battery cell industry. Strategic factors include unemployment rate factor around the facility and Human Development Index factor around the facility. Technological factors are: number of BTS (Base Transceiver Station) factors, smelter capacity factors, economic growth factors, tariffs and tax incentives, political factors, infrastructure factors.

While the competitive factors are the source of nickel raw materials available near the facility, the number of nickel smelter facilities near the facility, the factor of skilled construction workers around the facility, the regional minimum wage factor (UMR) around the facility, the power factor of PLN around the facility, the factor of electricity rates around the facility, company relationship factor, industry response time factor, logistic and facility cost factor, nickel smelter investment factor, construction cost index factor, construction expert factor, [9].

On the other side, a strategy formulation in supply chain aims to improve the performance. Many researchers had proposed methods to formulate strategy. Some company executives have difficulty understanding the relationship between supply chain processes horizontally and supply chain functions vertically. Thus, it is necessary to understand the supply chain process and supply chain function. However, there are still few companies that have an effective supply chain strategy [10].

Related to battery cell supply chain, below are previous research; Several previous studies discuss the dynamics and long-term impact of different EV diffusion scenarios on the battery supply chain and its environment in Germany. Other studies determine production locations to reduce social risks related to raw materials for electric vehicle battery companies by considering the placement of production facilities and sources of materials and components needed [11]. Research related to supply chain management also considering a green supply chain has also largely proposed by previous research [12], [13].

The level of readiness of lithium EV battery technology in Indonesia was obtained at TRL 5, fulfilled with a value of $82.50 \%$ in other studies [14]. Also a $10 \mathrm{kWh}$ mini battery factory according to financial and SWOT analysis, feasible from the NPV value side where the IRR and WACC levels indicate this project requires additional loans which are lower than the IRR [15]. UNS also examines the supply chain performance of the Lithium Battery Factory. The results are not optimal because the total value obtained is $65.13 \%$ and is included in the average category, and the low value is on responsiveness, agility, and efficiency of asset management with a value of 50 (average), 50 (mean) and 64.63 (mean) and need further improvement to improve the supply chain performance of Lithium Battery Factory [16].

\section{Analytical Hierarchy Process}

AHP is used to find the priority order of various alternatives in solving problems that are often faced. In life, we are often met with several alternative choices in solving a problem, and it is necessary to prioritize and test the consistency of the choices that have been taken. In very complex problems, decision making is strongly influenced by several and various factors, some of the main principles have been formulated by Saaty in the AHP method [17], [18].

Below are the main principals of AHP method to find weighted value of criteria:

a. Decomposition is a principle to describe and explain a problem in a hierarchical or structured manner, by solving the problem into separate parts. The separated parts are broken down again into parts into smaller levels, resulting in several levels to achieve more precise results. In the AHP method, the smallest parts are decomposed into a structure/hierarchy of criteria and alternatives.

b. Comparative judgement: An assessment of importance is relative to the two elements at a particular level that are being assessed in relation to the level above it. This assessment will affect the priority of the existing elements. By comparison in pairs, the relative importance of the criteria will be known. The results of this assessment are written in a pairwise comparison matrix.

c. Synthesis of priority is needed to get the weights on each element of the hierarchy and alternative elements. And to get local priority, look for the eigenvector in each pairwise comparison matrix. This is necessary because at each level there are pairwise comparison matrices, so a synthesis between local priorities is needed to get a global priority.

d. Logical consistency. Respondents have to have consistency in providing opinions when comparing elements, the results of the consistency assessment accepted are CR (Consistency Rati) 10\%. The AHP method has a functional hierarchy as the main tool with human perception as its main input, with this hierarchy it will be easy to solve complex or unstructured problems, and then can be arranged in a hierarchical form. In the process of forming a numerical score in ranking each alternative decision based on how the alternative should be matched with the decision-making criteria or called the AHP method [19]. 


\section{Composite Performance Index (CPI)}

CPI (Composite Performance Index) is a composite index that its use can determine the assessment or ranking of various alternatives (i) based on several criteria ( $\mathrm{j}$ ). The CPI method is a calculation model for decision making based on a performance index and can be used to provide an assessment of criteria that do not vary. The CPI method can be applied to excel or combined with other methods so that it will produce decisions from various criteria and good alternatives, the CPI method has good performance and useful for assessing industrial performance [20].

The following is a calculation procedure using the CPI method:

a. Identify criteria for positive trend (the higher the value the better), negative trend (lower the value the better), and categorize data types.

b. In the criteria categorized as trend $(+)$, which is changed to one hundred for the minimum value for each criterion, while the other values are transformed proportionally higher. NS trend calculation (+) can be seen in the Equation 1.

c. The criteria that are categorized as trend (-) are changed to one hundred for the minimum value for each criterion, while the other values transformed are proportionally lower. NS trend calculation (-) can be seen in Equation 2.

d. The calculation of the creative value is the sum of the multiplication of the criteria values with the criteria weights and the ranking of the total alternative values.

$$
\begin{aligned}
& \text { Trend }(+)=\left(\frac{N \text { Value }}{\text { Min Value }}\right) \times 100 \\
& \text { Trend }(-)=\left(\frac{\text { Min value }}{N \text { Value }}\right) \times 100
\end{aligned}
$$

\section{Determination of the Specific Location of the Plant Using the Center of Gravity Method}

In the previous stage, the identification of potential locations in each region was carried out based on the supply of raw materials and the market. At this stage, a specific location will be searched for the establishment of a cell battery factory. Gravity location models can be useful when identifying appropriate geographic locations within an area. The gravity model is used to find a location that minimizes the cost of transporting raw materials from suppliers and finished goods to the market/demand being served. Determining specific location for new facility in supply chain has also revealed at Ref. [9], [21]. Determine specific location enable for decision-maker to find the location effectively.
The following is a formulation for determining the specific location of the cell battery factory establishment with the center of gravity method:

a. Find distribution center locations that minimize distribution costs. One should consider: market location, volume of goods shipped to that market, shipping cost (or distance).

b. Place existing locations on the coordinate grid: the origin and scale of the grid are arbitrary, keep relative distances.

c. Calculate the $\mathrm{x}$ and $\mathrm{y}$ coordinates for the "center of gravity".

d. Assuming cost is directly proportional to distance and volume sent.

\section{Formulate Supply Chain Strategy}

The supply chain strategy is a comprehensive model and consists of various elements. Starting with understanding customer needs and various other input considerations. After that, this strategy will be forwarded to the development of new supply chain capabilities, performance measurement, and implementation in the field. Some of the important components in a supply chain strategy are customers, evaluation of supply chain game changers, competitors, technology surveys, supply chain risks, new supply chain capabilities, organizational evaluation, employees, and success measures, developing business cases and obtaining approval.

Research related to formulating supply chain strategy has been largely discussed. Ref. [22] design supply chain strategy with the combination of SWOT-AHP. Authors formulate strategy with expert judgement and validations. In other research, Ref. [23] design a fair profit allocation as a strategy to improve supply chain's competitive advantages. Related to supply chain risk, research that proposed risk mitigation to improve the performance including [24], [25].

\section{Research Method}

The research framework begins with formulating indicators of problems that will be carried out by researchers, then from the problems that arise, an analysis is carried out using three methods that are integrated with each other to obtain the main goal, namely the selection of areas for determining the location of EV battery factories in Indonesia, specific location findings, supply chain networks modeling and description and finally supply chain strategy for the effectiveness of supply chain model implementation.

Descriptive and quantitative methods were used to determine criteria and potential locations for the development of the EV battery industry. Primary data is collected through questionnaires from experts, secondary data from previous research studies, 
research bodies or government institutions. The research framework was created to control all research activities from data collection to research results. The research problem-solving framework is made to ensure that the research results can meet the requirements: data adequacy, data validity and reliability/feasibility of research results. Below are describe the research stages:

\section{Determine the Criteria and Potential Locations for the Development of the EV Battery Industry}

At this stage, a descriptive analysis is carried out on the potential of the raw material area and market for the sale of EV batteries, raw materials in the form of nickel, cobalt and other minerals, while the market is the EV industry. Some of the criteria for determining potential locations can be used as follows: location of supply sources and markets, location of potential facilities, estimated demand by market, cost of facilities, labor, and materials by location, cost of transportation between each pair of facility locations, cost of inventory by location and as a function of quantity, selling price of products in various regions, taxes and tariffs, desired response time and other service factors. With this information, it is possible to determine the potential location of EV battery factories in Indonesia by ranking [9].

After knowing the potential areas of raw materials and markets, the next step is to determine the most potential locations based on the criteria that have been compiled in stage I. At this stage, quantitative calculations are carried out using the Analytical Hierarchy Process (AHP) and Composite Performance Index (CPI) method.

This study looks for networks that maximize aftertax profits. For the sake of simplicity, that all requests have be met and taxes on income are ignored. However, it can be modified to include profits and taxes. The following are decision variables: quantity produced or shipped from a given facility, facility costs, transportation, and inventory.

\section{Determination of the Specific Location of the Plant Using the Center of Gravity Method}

In the previous stage, the identification of potential locations in each region was carried out based on the supply of raw materials and the market. At this stage, a specific location search will be carried out for the establishment of an EV battery factory. Gravity location models can be useful when identifying appropriate geographic locations within an area. The gravity model is used to find a location that minimizes the cost of transporting raw materials from suppliers and finished goods to the market/demand being served.
The following is a formulation for determining the specific location of the cell battery factory establishment with the center of gravity method:

a. The center of gravity method is a mathematical technique in finding the location of a distribution center that will minimize distribution costs or shipping costs.

b. Find distribution center locations that minimize distribution costs. Consider: Market location, Volume of goods shipped to that market, Shipping cost (or distance).

c. Place existing locations on the coordinate grid: the origin and scale of the grid are arbitrary, keep relative distances.

d. Calculate the $\mathrm{x}$ and $\mathrm{y}$ coordinates for the "center of gravity". Suppose that $x_{i}$ and $y_{i}$ as Coordinate $\mathrm{x}$ and $\mathrm{y}$ from location $i$, respectively, and $Q_{i}$ as the number of items moved to or from the location $I$, then the coordinates is calculate with Equation 3 and 4.

e. Assuming cost is directly proportional to distance and volume sent.

$$
\begin{aligned}
& \text { Coordinate- } x \text { center of grafity }=\frac{\sum x_{i} Q_{i}}{\sum Q_{i}} \\
& \text { Coordinate } y \text { center of grafity }=\frac{\sum y_{i} Q_{i}}{\sum Q_{i}}
\end{aligned}
$$

\section{Strategy Formulation for Implementing the $\mathrm{EV}$ Battery Industry Supply Chain Network}

In previous stages, the criteria for the potential location of the EV cell battery factory have been determined and the location of the regency/provincial area that has the potential to establish an EV cell battery factory based on the source/supply of nickel raw materials and from the plan where the EV factory will be established qualitatively. And phase 2 has identified the location of the cell battery factory in the district/province with primary data and asked the opinions of experts and experts in their field, then data processing is carried out with AHP-CPI.

After that, the coordinates ( $\mathrm{x}$ and $\mathrm{y}$ axes) of the EV battery factory will be determined using the center of gravity method. Cell battery industry supply chain network to support the electric car industry. As the final stage, of course the supply chain network has various weaknesses and strengths that need to be identified to support its application in the field.

To strengthen the research results, it is necessary to discuss and ask for opinions or input from experts who have previously provided an assessment of the criteria from alternative locations to establish the most appropriate EV battery factory so as to optimize the EV battery supply chain network in Indonesia. The strategy formulation for strengthening the supply chain performance is adopted from [22], [26]. 


\section{Data Acquisition and Collection}

The data collected in this study include primary and secondary data. Primary data is obtained directly from the source, while secondary data is obtained from the results of previous research/study. Primary data includes criteria for determining factory locations, strengths, and weaknesses of the cell battery industry supply chain network as well as information on supply chain network implementation strategies obtained from experts, as shown in Table 1. Secondary data in the form of quantitative data needed to determine the location of the required factory. The secondary data was collected from report, previous research and statistical data that published by related organizations.

Table 1. Expert background

\begin{tabular}{||cll||}
\hline No & Skills Background & \multicolumn{1}{c|}{ Areas of expertise } \\
\hline \hline 1 & Academic Institution & Supply Chain System \\
2 & Industrial Practitioner & $\begin{array}{l}\text { Nickel smelter } \\
\text { company engineer } \\
\end{array}$ \\
3 & Industrial Practitioner & $\begin{array}{l}\text { Mining company } \\
\text { auditor }\end{array}$ \\
4 & Government & Dept. of Industry expert \\
& Institutions & staff \\
\hline
\end{tabular}

\section{Result and Discussion}

\section{Determination and Weighting of Criteria for Determining Factory Location}

To decide the facility locations, criteria have to be considered. This research proposed 14 criteria based on the literature review and expert discussion. The criteria to decide the facility location of the battery industry is showed at Table 2 .
Due to the criteria are scoping many areas, experts are provided judgements to define the importance level of the criteria. Criteria to determine the facility locations is calculated using Analytical Hierarchy Process (AHP) which proposed by Ref. [17]. The hierarchy for this case is depicted at Figure 1.

At the Figure 1, there 3 level of AHP model. At the first level is the goal to find the importance level of the criteria for alternative location selections. At the level 2, 14 criteria of the location selection is delivered. These criteria are found based on literature review and expert validation. Finally, 7 alternative locations for battery industry development are stated at the $3^{\text {rd }}$ level of AHP model.

\section{Weighting Criteria For Selecting EV Battery} Factory Locations In Indonesia

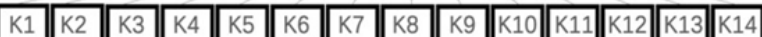

\section{[HALMAHERA SELATAN] MOROWAO KONAWE SOROWAKO PPATMBAN CIIAARANG BATANG}

Figure 1. Hierarchical model of criteria

The criterion value of the comparison matrix of each expert/expert is made up of the average comparison criteria values of the four experts using the geometric mean and pair-ways comparison. The pair-ways comparison of 4 experts is showed at Table 3. The results of the calculation of the value of the weight of the criteria and the level of consistency of the expert's assessment can be seen in Table 6 . The consistency of the assessment of the experts/experts is 0.06 which is less than $10 \%(0.1)$ meaning that the expert has given consistent rating.

Table 2. Criteria weight and consistency

\begin{tabular}{|l|c|c|c||}
\hline \multicolumn{2}{|c|}{ Expert Inconsistency } & Normalized & Idealized \\
\hline Information & Name & 0.12 & 1.00 \\
\hline Nickel resources & K1 & 0.10 & 0.79 \\
\hline Smelter Plant Capability & K2 & 0.06 & 0.50 \\
\hline Number of BTS & K3 & 0.06 & 0.50 \\
\hline Construction Cost Index & K4 & 0.06 & 0.47 \\
\hline Construction experts & K5 & 0.06 & 0.53 \\
\hline Construction skilled workers & K6 & 0.09 & 0.75 \\
\hline Regional minimum wage & K7 & 0.08 & 0.67 \\
\hline Electricity/PLN capable power & K8 & 0.08 & 0.67 \\
\hline Industrial electricity rates & K9 & 0.05 & 0.42 \\
\hline Human development index & K10 & 0.05 & 0.38 \\
\hline Growth Level of the Economy & K11 & 0.05 & 0.45 \\
\hline Open Unemployment Rate & K12 & 0.05 & 0.40 \\
\hline GRDP-per capita & K13 & 0.08 & 0.66 \\
\hline Transportation costs & K14 & 1.00 & \\
\hline Total weight of criteria & & & \\
\hline
\end{tabular}


Table 3. Pair-ways comparison of expert judgement

\begin{tabular}{|c|c|c|c|c|c|c|c|c|c|c|c|c|c|c||}
\hline Criteria & K1 & K2 & K3 & K4 & K5 & K6 & K7 & K8 & K9 & K10 & K11 & K12 & K13 & K14 \\
\hline K1 & 1.00 & 1.26 & 5.23 & 3.08 & 2.24 & 2.24 & 3.34 & 1.00 & 1.50 & 1.32 & 0.71 & 1.52 & 1.32 & 1.32 \\
\hline K2 & 0.80 & 1.00 & 1.97 & 2.59 & 1.32 & 1.50 & 1.88 & 1.09 & 1.93 & 0.67 & 0.67 & 0.88 & 0.67 & 1.50 \\
\hline K3 & 0.19 & 0.51 & 1.00 & 1.00 & 0.58 & 0.51 & 0.67 & 1.32 & 1.50 & 0.60 & 0.32 & 0.82 & 0.36 & 0.71 \\
\hline K4 & 0.32 & 0.39 & 1.00 & 1.00 & 0.71 & 1.00 & 0.88 & 0.45 & 0.76 & 0.51 & 0.51 & 0.88 & 0.47 & 0.58 \\
\hline K5 & 0.45 & 0.76 & 1.73 & 1.41 & 1.00 & 1.00 & 2.59 & 1.32 & 2.94 & 1.19 & 1.00 & 1.50 & 1.00 & 1.00 \\
\hline K6 & 0.45 & 0.67 & 1.97 & 1.00 & 1.00 & 1.00 & 0.88 & 0.51 & 0.76 & 0.67 & 0.67 & 1.24 & 0.67 & 0.95 \\
\hline K7 & 0.30 & 0.53 & 1.50 & 1.14 & 0.39 & 1.14 & 1.00 & 0.45 & 0.64 & 0.45 & 0.41 & 0.84 & 0.32 & 1.00 \\
\hline K8 & 1.00 & 0.92 & 0.76 & 2.24 & 0.76 & 1.97 & 2.24 & 1.00 & 1.78 & 0.84 & 0.54 & 1.78 & 0.71 & 0.71 \\
\hline K9 & 0.67 & 0.52 & 0.67 & 1.32 & 0.34 & 1.32 & 1.57 & 0.56 & 1.00 & 0.39 & 0.29 & 0.63 & 0.30 & 0.47 \\
\hline K10 & 0.76 & 1.50 & 1.65 & 1.97 & 0.84 & 1.50 & 2.21 & 1.19 & 2.59 & 1.00 & 1.57 & 2.21 & 1.57 & 2.06 \\
\hline K11 & 1.41 & 1.50 & 3.16 & 2.47 & 1.00 & 1.50 & 2.45 & 1.86 & 3.50 & 0.64 & 1.00 & 1.41 & 1.00 & 0.71 \\
\hline K12 & 0.66 & 1.14 & 1.22 & 1.14 & 0.67 & 0.80 & 1.57 & 0.56 & 1.58 & 0.45 & 0.71 & 1.00 & 0.71 & 0.54 \\
\hline K13 & 0.76 & 1.50 & 2.78 & 2.11 & 1.00 & 1.71 & 2.51 & 1.41 & 3.31 & 0.64 & 1.00 & 1.41 & 1.00 & 1.41 \\
\hline K14 & 0.76 & 0.67 & 1.41 & 1.73 & 1.00 & 1.06 & 0.80 & 1.41 & 2.11 & 0.49 & 1.41 & 1.86 & 0.71 & 1.00 \\
\hline
\end{tabular}

Table 4. Data and weight for criteria to determine potential locations

\begin{tabular}{|c|c|c|c|c|c|c|c|c|c|c|c|c|c|}
\hline Criteria & K1 & K2 & K3 & K4 & $\overline{\mathrm{K} 55}$ & "K6 & K7 & K8 & K9 & K10 & "K11 & K12 & K13 \\
\hline Weight & 0.12 & 0.1 & 0.06 & 0.06 & 0.06 & 0.06 & 0.09 & 0.08 & 0.08 & 0.05 & 0.05 & 0.05 & 0.05 \\
\hline $\begin{array}{l}\text { Halmahera } \\
\text { (North } \\
\text { Maluku) }\end{array}$ & 29.00 & 0.7385 & 294 & 119.11 & 505 & 2,776 & $2,721,530$ & 58.13 & $1,162.46$ & $68.49 \%$ & $9.48 \%$ & $6.97 \%$ & $88,831,801.2$ \\
\hline $\begin{array}{l}\text { Morowali } \\
\text { (Central } \\
\text { Sulawesi) }\end{array}$ & 29.84 & 4.229 & 615 & 91.98 & 3,838 & 12,918 & $2,823,965$ & 175.70 & $1,186.97$ & $69.55 \%$ & $4.99 \%$ & $3.77 \%$ & $16,110,224.0$ \\
\hline $\begin{array}{l}\text { Konawe } \\
\text { (South- } \\
\text { Southeast) }\end{array}$ & 10.39 & 0.726 & 584 & 101.45 & 1,615 & 6,905 & $2,552,014$ & 44.83 & $1,136.46$ & $71.20 \%$ & $6.58 \%$ & $4.58 \%$ & $36,736,666.7$ \\
\hline $\begin{array}{l}\text { Sorowako- } \\
\text { (South } \\
\text { Sulawesi) }\end{array}$ & 12.77 & 0.156 & 1,112 & 97.34 & 8,715 & 14,136 & $3,103,800$ & 56.75 & $1,066.93$ & $71.93 \%$ & $6.84 \%$ & $5.36 \%$ & $69,990,000.0$ \\
\hline $\begin{array}{l}\text { Patimban- } \\
\text { Subang } \\
\text { (West Java) }\end{array}$ & 0.00 & 0.00 & 4,027 & 103.03 & 13,641 & 35,883 & $3,064,218$ & 102.74 & $1,111.71$ & $72.03 \%$ & $5.07 \%$ & $8.04 \%$ & $27,300,574.9$ \\
\hline $\begin{array}{l}\text { Batang } \\
\text { (Central } \\
\text { Java) }\end{array}$ & 0.00 & 0.00 & 4,257 & 97.21 & 6,937 & 25,618 & $2,129,117$ & 23.19 & $1,105.78$ & $71.87 \%$ & $6.48 \%$ & $6.48 \%$ & $16,110,224.7$ \\
\hline $\begin{array}{l}\text { Cikarang } \\
\text { (West Java) }\end{array}$ & 0.00 & 0.00 & 4,027 & 101.05 & 13,641 & 35,883 & $3,064,218$ & 102.74 & $1,111.71$ & $72.03 \%$ & $5.07 \%$ & $8.04 \%$ & $50,489,343.4$ \\
\hline
\end{tabular}

Table 5. Ranking results of 7 alternative battery factory locations using the CPI method

\begin{tabular}{|c|c|c|c|c|c|}
\hline \multirow{2}{*}{ Alternative Location } & \multicolumn{3}{|c|}{ K14 } & \multirow{2}{*}{ Total Score } & \multirow{2}{*}{ Ranking } \\
\hline & Patimban & Cikarang & Batang & & \\
\hline Halmahera (North Maluku) & 190.4267 & 189.00005 & 188.9895 & 189.4721 & 6 \\
\hline Morowali (Central Sulawesi) & 487.4536 & 486.13368 & 486.0864 & 486.5579 & 1 \\
\hline Konawe (South-Southeast) & 171.2362 & 169.91635 & 169.9286 & 170.3604 & 7 \\
\hline Sorowako (South Sulawesi) & 262.7240 & 261.40409 & 261.4548 & 261.8610 & 5 \\
\hline Patimban-Subang (West Java) & 410.2656 & 413.19225 & 411.2341 & 411.5640 & 3 \\
\hline Batang (Central Java) & 285.2237 & 285.45302 & 291.6368 & 287.4368 & 4 \\
\hline Cikarang (West Java) & 417.3246 & 423.73463 & 417.5539 & 419.5378 & 2 \\
\hline
\end{tabular}

\section{Determination of a Potential Location for an $\mathrm{EV}$ Battery factory using CPI}

Potential locations are determined through the CPI technique by taking into account the secondary data of each alternative and the weight of each criterion from the AHP technique. Prepare a criteria table consisting of 14 criteria from each potential alternative location of the EV battery factory which consists of 7 locations, equipped with positive or negative effects on the potential EV battery factory location, as shown in Table 4.

The ranking of alternative locations for EV battery factories can be calculated using the CPI (Composite Performance Index) method by combining various alternative locations based on several location 
criteria. From the results of the multiplication calculation of combining the weights of the AHP criteria with the criteria weights from the potential alternative factory locations, the ranking results are obtained as in Table 5. From the AHP-CPI calculation, the highest-ranking value is obtained from the alternative location of the EV cell battery factory in Indonesia, which is in Morowali-Sulawesi. Middle with a value of 486.5579 .

\section{EV battery Factory Supply Chain Network Formulation}

In the previous discussion, the best factory location is in Morowali - Central Sulawesi, to optimize the supply chain network, it will take into account the existing smelter plant in Central Sulawesi by considering the coordinates and capacity of the nickel smelter plant.

After finding the coordinate points and production capacity of the nickel smelter plant in Central Sulawesi, the coordinates of the EV battery factory will be determined using the center of gravity method to optimize the supply chain network. So that the coordinates of the EV battery factory are obtained to optimize the supply chain network at the coordinate points: $\mathrm{XG}=-2.55286495385115$, and $\mathrm{YG}=$ 121.863987538114 as showed in Table 6.

Table 6. Coordinates of the EV battery factory for optimizing the network

\begin{tabular}{|c|c|c|c|c|c|c|}
\hline No & Nickel Smelter factory name & $\begin{array}{l}\text { Production per year } \\
\text { (Ton) }\end{array}$ & $X i$ & Yi & 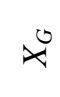 & $\Delta$ \\
\hline 1 & PT. Sulawesi Mining Investment (SMI) & 300,000 & -2.825 & 122.161 & \multirow{17}{*}{ 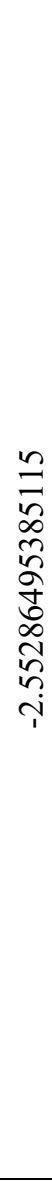 } & \multirow{17}{*}{ 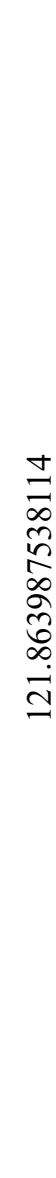 } \\
\hline 2 & PT. COR (Central Omega Resources) Tbk. & 100,000 & -1.946 & 121.336 & & \\
\hline 3 & PT.BNI (Broly Nickel Industry/ PT. IMIP & 507,000 & -2.822 & 122.156 & & \\
\hline 4 & PT. Gunbuster Nickel Indonesia (PT.GNI). & $1,800,000$ & -1.994 & 121.431 & & \\
\hline 5 & PT Tsingshan Steel Indonesia (TSI) & 600,000 & -2.832 & 122.167 & & \\
\hline 6 & PT.Hengjaya Nickel Industri (HNI). & 150,000 & -2.847 & 122.164 & & \\
\hline 7 & PT.Ranger Nickel Industry (PT.RNI) & 150,000 & -2.851 & 122.163 & & \\
\hline 8 & $\begin{array}{l}\text { PT.Artabumi Sentra Industri (ASI) / PT. } \\
\text { Teknik Alum Service (PT.TAS) }\end{array}$ & 729,600 & -3.017 & 122.232 & & \\
\hline 9 & PT. Genba Multi Mineral (PT.GMM) & 500,000 & -2.156 & 121.479 & & \\
\hline 10 & PT.Huayaue Nickle \& Cobalt (PT.HYNC) & 60,000 & -2.852 & 122.179 & & \\
\hline 11 & $\begin{array}{l}\text { PT.Qing Mei Bang New Energy Materials } \\
\text { Indonesia (PT.QMB) }\end{array}$ & 50,000 & -2.859 & 122.166 & & \\
\hline 12 & PT Wanxiang Nickel Indonesia (PT.WNI) & 900,000 & -2.733 & 122.030 & & \\
\hline 13 & PT. Sulawesi Resources (PT.SR) & 152,400 & -2.704 & 121.988 & & \\
\hline 14 & PT.Ang And Fang Brother (PT.AAFB) & 130,508 & -2.789 & 122.083 & & \\
\hline 15 & $\begin{array}{l}\text { PT. Indonesia Guang Ching Nickel and } \\
\text { Stainless Steel Industry (PT.GCNS-B) }\end{array}$ & 600,000 & -2.856 & 121.850 & & \\
\hline 16 & $\begin{array}{l}\text { PT. Tsingshan Nickel Iron Indonesia /PT } \\
\text { Indonesia Tsingsahn Stainless Steel }\end{array}$ & 100,000 & -2.831 & 122.167 & & \\
\hline 17 & $\begin{array}{l}\text { PT.TMM (PT Trinitan Metals and Minerals } \\
\text { Tbk)/PT Bangun Palu Sulawesi Tengah } \\
\text { (BPST) }\end{array}$ & 5,000 & -0.727 & 119.913 & & \\
\hline \multicolumn{5}{|c|}{ Battery Factory: Bente, Central Bungku, Morowali Regency, Central Sulawesi } & 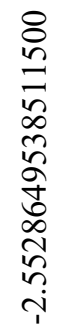 & 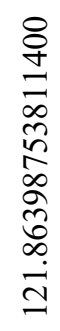 \\
\hline
\end{tabular}




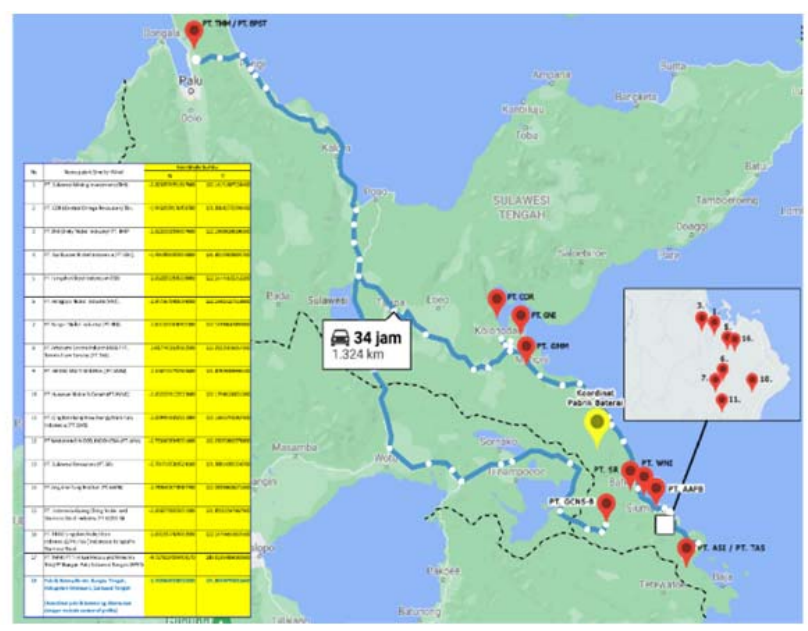

Figure 2. Location and coordinates of optimal EV battery factory supply chain network

Central Bungku, Morowali Regency, Central Sulawesi with coordinates: $x_{G}=-2.55286495385115$, and $y_{G}=121.863987538114$, can be seen in Figure 2 which is located at Bente village, a village in Bungku Tengah sub-district, Morowali, Central Sulawesi and still green land and about $11 \mathrm{~km}$ to the highway. After reviewing the nearest environmental facilities, there is the IMIP-Morowali industrial area, which has complete facilities, with a distance of $45 \mathrm{~km}$ from the coordinate point in Bente village, meaning that this research is in accordance with current developments.

In this stage, the main driver of the supply chain had been found at Morowali, Central Sulawesi. As mentioned by Ref. [27], industry is the core operations of the supply chain. Therefore, due to the location of the battery industry has been define, this research proposed down-stream and up-stream part of the battery cell supply chain in Indonesia.
Determining the supply chain configuration is the main stage in supply chain analysis [23]. The supply chain configuration organized by stakeholders, information, and raw material flow in the supply chain. This research proposed a supply chain configuration for the battery cell industry in Indonesia, as shown in Figure 3.

Generally, there are 4 sections in supply chain configurations, raw material source, battery cell production actor, distribution, costumer, and recycling process. Nickel smelters are the raw material source while the electric vehicle industries are potential costumer which is located in the Java Island.

\section{Model Validation for Supply Chain Implementation and Strategy}

To strengthen the results of this study, researchers need to discuss and ask for opinions or input from experts who have previously provided an assessment of the criteria from alternative locations to establish the most appropriate EV battery factory so as to optimize the EV battery supply chain network in Indonesia. So the researchers asked some questions as follows:

1. The advantages and disadvantages of the EV battery industry in Indonesia.

2. The advantages and disadvantages of the EV battery industry supply chain with its factory location in IMIP-Morowali.

3. The potential sustainability of the EV battery industry supply chain in Indonesia.

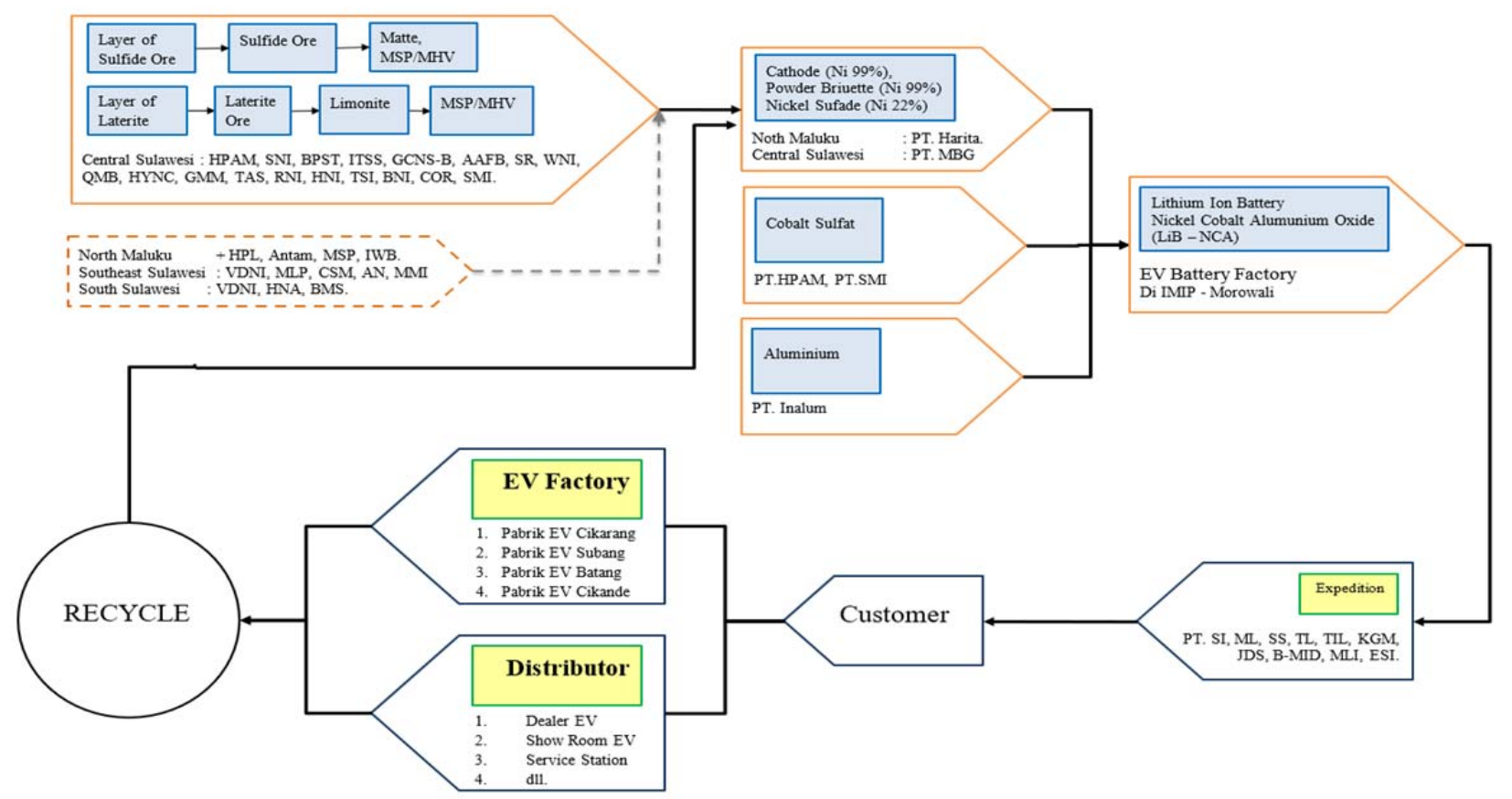

Figure 3. Proposed supply chain network for battery cell industry 


\section{Expert-1: Academician in Supply Chain Engineering}

The EV battery industry in Indonesia has the advantage of having abundant nickel sources and is supported by smelter factories that are already operating and even precursor factories for making battery raw materials such as cathodes have begun to be built and some are even operating as in the IMIPMorowali industrial area. Another advantage is that there is already an electric car factory built in Indonesia, namely Hyundai, and even other manufacturers have also planned to produce electric cars/EVs in Indonesia.

The weakness of the EV battery industry in Indonesia is that battery technology is currently owned by Europe and China, and research on EV battery technology is still being carried out by brand holders, and not by the government or other independent bodies. Another drawback is the absence of special ports such as in IMIP-Morowali at the destination of car factories such as Patimban-Subang, Tanjung Mas - Batang. There has even been no realization of the Cikarang dry port for container ports from Tanjung Priok to industries such as the Hyundai EV factory in Deltamas - Cikarang. The mode of transportation for supply of nickel raw materials from the mine to the smelter and from the smelter outside IMIP to the IMIP-Morowali area from the smelter factory and nickel mining to the smelter.

The location of the EV battery factory in Morowali is the right choice because it is supported by facilities such as the port itself, where there is already a loading and unloading service company that manages it, even raw materials from ships can go directly to the factory via conveyors, as well as liquid materials, other supporting gases can sent from ships to factories in the IMIP area via pipelines and vice versa. Even the IMIP-Morowali area is the most complete area today, supported by a private airport, smelter factory, precursor factory, and other utility facilities. Even the area is in the city of Bahodopi sub-district.

From the supply chain network and supply chain strategy of EV battery factories that have been described, ranging from nickel mining to electric $\mathrm{car} / \mathrm{EV}$ factories that have been integrated, to make Indonesia the main electric car industry in ASEAN, it is necessary to have a grand strategy about electric cars. /EV Indonesia, for example, has its own brand by mastering technology by financing research on electric cars and electric car batteries and building human resources by transferring technology by providing incentives to investors.

\section{Expert-2: Practitioners in Nickel mining and smelters}

Indonesia has the largest nickel source in the world and is supported by the government's prohibition on the export of nickel ore unless domestic demand has been met, and even then, nickel with a grade above $1.7 \%$. This forces nickel mining investors to set up smelter factories in the country. Another advantage is the existence of a presidential regulation on the acceleration of electric cars as well as on the General National Energy Plan which can stimulate the establishment of electric car factories in Indonesia, which of course also the establishment of electric $\mathrm{car} / \mathrm{EV}$ batteries in Indonesia.

The weakness is in terms of transportation, where it is still difficult to get fuel for heavy equipment that is mined for nickel, if fuel supply is disrupted it can affect supply to smelter and precursor factories both in price and delivery time. Coal fuel for PLTU as a smelter or precursor power plant and battery factory, which can cause air pollution, and there is a ban on the use of coal as fuel. Permits and regulations that sometimes overlap, especially IUPs (Mining Business Permits) which can have multiple ownership, then IUPs which are split due to regional expansion.

The IMIP-Morowali industrial area is the right choice for establishing an EV battery factory industry, which is supported by complete facilities ranging from ports, airports, management of area utility's needs, lodging and even loading and unloading of goods at the port. The area is also close to the city. Bahodopi district. Even the smelter plant is in the Region with the largest capacity in Indonesia.

From several references from previous studies, none of them are the same or similar to the research conducted by the author, where the researcher examines where the best EV battery factory in Indonesia should be to get an optimal supply chain network. Meanwhile, the sources of nickel and cobalt raw materials are mostly in Sulawesi, then in North Maluku, and smelter and battery precursor plants already exist or are being built or planned in these areas.

Meanwhile, an EV factory has been built on the island of Java in Cikarang, and will be built in Subang, West Java, there is also a discourse that it will be built in Batang, Central Java, and recently the car manufacturer DFSK will produce EV cars in Serang Banten, while Toyota will produce EVs in Jakarta. /Karawang, Mitsubishi Xpander also does not want to be left behind and will produce EVs in Cakung, East Jakarta. Whether the EV battery factory will be built and brought closer to the source of raw materials and smelters and pressors, or closer to the EV factory market on the island of Java which 
is separated by the ocean. On the one hand, there is no battery factory in Indonesia and no EV factory is operating, even EV cars are still new to the Indonesian people and the price is still relatively expensive for most Indonesians. So, from the conditions described above which are very complex, this research is a new thing in Indonesia.

\section{Conclusion}

This research has been succeeded to formulate supply chain configuration and strategy for battery cell industry in Indonesia. The location for the development of the electric car/EV battery industry with the most potential is the first in the IMIPMorowali industrial area, Central Sulawesi. The second is in the Delta Mas-Cikarang industrial area, West Java. And the third is in Patimban-Subang, West Java. The supply chain network can be optimized by finding the coordinates of the EV battery factory by calculating the coordinates and capacity of the smelter plant in the potential area and calculating the factor of the closest facility to the area. Optimization is also calculated against the distance and capacity of the destination market. The supply chain strategy for the EV battery industry in Indonesia is to master EV battery technology by conducting research and improving human resources through training and technology transfer from investors by providing incentives. Providing the electric car/EV industry from upstream to downstream, developing infrastructure such as special ports in locations closest to industrial areas and building rail carriages.

For further research, due to the potential location and supply chain network had been found, a feasibility analysis is required. The feasibility analysis with related factors is necessary to strengthen the policy to develop the industry.

\section{References}

[1]. Haider, W. H. (2020, January). Estimates of total oil $\&$ gas reserves in the world, future of oil and gas companies and smart investments by $\mathrm{E} \& \mathrm{P}$ companies in renewable energy sources for future energy needs. In International Petroleum Technology Conference. OnePetro. doi: 10.2523/iptc-19729-ms.

[2]. World Health Organization. (2006). Air quality guidelines: global update 2005: particulate matter, ozone, nitrogen dioxide, and sulfur dioxide. World Health Organization.

[3]. Haryanto, B. (2018). Climate change and urban air pollution health impacts in Indonesia. In Climate Change and Air Pollution (pp. 215-239). Springer, Cham. doi: 10.1007/978-3-319-61346-8_14.
[4]. Subekti, R. A., Sudibyo, H., Susanti, V., Saputra, H. M., \& Hartanto, A. (2014). Peluang dan Tantangan Pengembangan Mobil Listrik Nasional. LIPI Press.

[5]. Firdiyono, F., Sulistiyono, E., Lalasari, L. H., Arwanda, M. R., \& Wahyuningsih, S. (2019, February). Adsorption of lithium in the manganese hydroxide precipitation processes. In IOP Conference Series: Materials Science and Engineering (Vol. 478, No. 1, p. 012011). IOP Publishing. doi: 10.1088/1757-899X/478/1/012011.

[6]. International Energy Agency. (2017). 2016, Jumlah Mobil Listrik Mencapai 2 Juta Unit. Databoks.

[7]. Omazaki Group.(2021). Baterai Mobil Listrik dan Karakteristiknya. Retrieved from: https://www.omazaki.co.id/baterai-mobil-listrik/ [accessed: 10 June 2021].

[8]. P. Schönsleben.,(2010). Integral Logistic Management: Operations and Suppl Chain Management in Comperhensive Value-Added Networks, 3rd ed. Boca Raton: Taylor \& Francis Group.

[9]. Chopra, S., Meindl, P., \& Kalra, D. V. (2013). Supply chain management: Strategy, planning, and operation (Vol. 232). Boston, MA: Pearson.

[10]. Dittmann, J. P. (2013). Supply chain transformation: building and executing an integrated supply chainstrategy. McGraw-Hill.

[11]. Thies, C., Kieckhäfer, K., Spengler, T. S., \& Sodhi, M. S. (2019). Assessment of social sustainability hotspots in the supply chain of lithium-ion batteries. Procedia CIRP, 80, 292-297. doi: 10.1016/j.procir.2018.12.009.

[12]. K. S. Iphov, Y. Arkeman, S. Dahrul, and M. Marimin.(2013). "Designing Green Supply Chain Management in Cocoa Agroindustry: Problem Identification and PRofilling," Proceeding, 6th Int. Semin. Ind. Eng. Manag., no. February, pp. 81-89.

[13]. Tong, Y. (2017). Model for evaluating the green supply chain performance under low-carbon agricultural economy environment with 2-tuple linguistic information. Journal of Intelligent \& Fuzzy Systems, 32(3), 2717-2723. doi: 10.3233/JIFS-16802.

[14]. Suzianti, A., Dewi, A. P., Mubarak, A., \& Shafira, N. D. (2020, May). Technology readiness level assessment of lithium battery in Indonesia for national electric vehicle program. In AIP Conference Proceedings (Vol. 2227, No. 1, p. 040010). AIP Publishing LLC. doi: 10.1063/5.0001010.

[15]. Sutopo, W., Atikah, N., Purwanto, A., \& Nizam, M. (2013, November). The battery $10 \mathrm{kWh}$ : A financial analysis of mini manufacturing plant. In 2013 Joint International Conference on Rural Information \& Communication Technology and Electric-Vehicle Technology (rICT \& ICeV-T) (pp. 1-6). IEEE. doi: 10.1109/rICT-ICeVT.2013.6741512.

[16]. Ikasari, N., Sutopo, W., \& Zakaria, R. (2020, October). Performance Measurement in Supply Chain Using SCOR Model in The Lithium Battery Factory. In IOP Conference Series: Materials Science and Engineering (Vol. 943, No. 1, p. 012049). IOP Publishing. doi: 10.1088/1757-899X/943/1/012049. 
[17]. Saaty, T. L. (2016). The analytic hierarchy and analytic network processes for the measurement of intangible criteria and for decision-making. In Multiple criteria decision analysis (pp. 363-419). Springer, New York, NY. doi: 10.1007/0-387-23081-5_9.

[18]. Saaty, T. L. (2008). Decision making with the analytic hierarchy process. International journal of services sciences, 1(1), 83-98. https://doi.org/10.1504/IJSSci.2008.01759.

[19]. Sonata, F. (2018). Analisis Studi Kelayakan Pelayanan E-Commerce Menggunakan Metode Analytical Hierarchy Process (ahp). Jurnal Komunika: Jurnal Komunikasi, Media dan Informatika, 7(2), 58-71.

[20]. M. Marimin and N. Maghfiroh, Aplikasi Teknik Pengambilan Keputusan dalam Manajemen Rantai Pasok (Application for Decision Making Technique in Supply Chain Management). Bogor (ID): IPB Pr, 2010.

[21]. Heizer J., B. Render, and C. Munson.(2017). Operations Management: Sustainability and Supply Chain . 12th ed. Essex: Pearson Education Limited.

[22]. Asrol, M., Marimin, M., \& Machfud, M. (2017). Supply chain performance measurement and improvement for sugarcane agroindustry. International Journal of Supply Chain Management, 6(3), 8-21.
[23]. Asrol, M., Yani, M., \& Taira, E. (2020). Supply chain fair profit allocation based on risk and value added for sugarcane agro-industry. Operations and Supply Chain Management: An International Journal, 13(2), 150-165

[24]. Pujawan, I. N., \& Geraldin, L. H. (2009). House of risk: a model for proactive supply chain risk management. Business Process Management Journal, 15(6), 953-967. doi: 10.1108/14637150911003801.

[25]. Septiani, W., Marimin, Herdiyeni, Y., \& Haditjaroko, L. (2016, October). Risk dependency chain model of dairy agro-industry supply chain using fuzzy logic approach. In Supply Chain Forum: An International Journal (Vol. 17, No. 4, pp. 218-230). Taylor \& Francis. doi: 10.1080/16258312.2016.1232945.

[26]. F. David.(2011).Strategic Management; Concepts and Cases., Thirteen E. Boston (US): Prentice Hall.

[27]. Ganesh Kumar, C., Murugaiyan, P., \& Madanmohan, G. (2017). Agri-food supply chain management: literature review. Intelligent Information Management, 9, 68-96. doi: 10.4236/iim.2017.92004. 